\title{
Corporate Social Responsibility and Effectiveness of Small and Medium Enterprises (Smes) In Nigeria.
}

\author{
${ }^{1}$ Olusanya, Samuel Olumuyiwa, ${ }^{2}$ Awotungase, Suleiman Adelaja, ${ }^{3}$ Oyebo, \\ Afees Oluwatosin \\ ${ }^{I}$ Lecturer Lagos State University External System. Economics Department. \\ ${ }^{2}$ Lecturer Lagos State University External System Business Administration Department Associate Lecturer Saint \\ Augustines' College Of Education Akoka \\ ${ }^{3}$ Lecturer Lagos State University External System. Marketing Department.
}

\begin{abstract}
The research study takes a look at the relationship between corporate social responsibility and some dimensions of organizational effectiveness of Nigerian Small and Medium Scale Enterprises. Data were collected by means of questionnaires administered to selected SMEs in Lagos state. The study generated sixty percent response rate from two hundred and nine SMEs existing for more than five years. Responses from the survey were statistically analyzed using descriptive statistics, and product moment correlation. The results of the study indicated that Nigerian SMEs operators were actively involved in business ethics, urban and consumer affairs, but least involved in environmental affairs. The study showed that organizational effectiveness of the participating firms is to large extent satisfactory. However, the study concludes and recommends that the involvements in corporate social responsibility were found to correlate positively with organizational effectiveness and that the government should encourage the Nigerian SMEs investors in some aspects of corporate social responsibility and monitoring of SMEs environmental affairs.
\end{abstract}

Key words: Corporate social responsibility, Organizational effectiveness, Smal and Medium Enterprises (SMEs)

\section{Introduction}

Corporate social responsibility is a nebulous concept that has been described in a number of ways, it is widely used in literature of sociology, anthropology, economics, politics and business administration .Most writers on corporate social responsibility see the concept as the disposition of an organization to exhibit "missionary" rather than "mercenary" attitudes toward the society. Corporate social responsibility in relation to business is the obligation of a business organization to pursue those lines of action, which are desirable in terms of objectives, and values of society. (Lawal and Sulaimon, 2007) defined it as " intelligent and objective concern, which restrains individual or corporate behaviour from ultimately destructive activities, no matter how immediately profitable, and leads to the direction of the positive contribution to human betterment" .Presumably, corporate executives as agents of the owners are to be responsible for conducting the business in accordance with the desire of the owner while conforming to the basic rules of the society. The responsibility has three broad facets (Ikpeze, 1981).First, contribution to charity. Second, elimination of social costs. The third facet of social responsibility is the adoption and observance of ethical codes aimed at reducing business malpractices.

Nigeria business organization and other types of business must be seen in many actions domains can pursue social responsibility in areas such as: concern for ecology and environment, commitment to quality, truth in advertisement, customer satisfaction and education. Other concern include service to community needs, fair employment practices, progressive labour relations, employment assistance and corporate philanthropy.(Ogbeuchi, 1998)

Dangers associated with the neglect of social responsibility obligation by business organization represent a cost which can be envision in monetary value lost in man-hour, when production are stopped forcefully, by the local community in which in production I taken place such as the one happening in oil exploration community. The same reasoning could be extended to stoppage of construction work, on building by off- springs of landlords. There is always colossal loss in both natural and man-made resources to business organization when they neglect social responsibility and ethics in the management of the environment where they operate. The cost involved when organization are not socially responsible are of two types; firstly, cost in cash outlay, and secondly, cost of disruptive action by the community forcing social responsibility on the organization.

Organization's commitment to corporate social responsibility protects the organization by doing the minimum legally required to satisfy expectation. Accommodative approach (do the minimum ethical required) is an acknowledgement of the need to support social responsibility. Organizations adopting such strategy accept their social responsibility role and try to satisfy criteria of economic, legal and ethical responsibility. Proactive 
Corporate Social Responsibility And Effectiveness Of Small And Medium Enterprises (Smes) In

approach to social responsibility is designed to meet all the criteria of social performance, managers taken a proactive approach embrace the need to behave in socially responsible and gout of their ways to learn about the needs of different stakeholders and are willing to utilize organizational resources to pursue the interest of the stakeholders. (Ogbeuchi, 1998).

\section{Literature Review And Theoretical Framework}

Corporate social responsibility relate to expectations, societal valued relationships, and moral aspect of group and organizations. Modern business exercises extensive influence on our social and economic life styles. As social institution it is responsible to deliver a standard of living and maximize life quality. Today, life quality means not only quality and quantity of consumer goods and services, but also enriched quality of the life in society and the environment. There is also demand for social responsiveness of business organization, which means, the totality, and preparedness of organizations to relate their plans and policies to the social environment in mutually beneficial ways to both the employees and the society. Organization is expected to behave in socially beneficial ways particularly in relation to the physical environment, product quality, and removal of unfair discrimination in hiring and firing staff. New attitude towards the managerial roles is slowly emerging; organization is required as agent of social change and not merely as agent of economic and technical change and Organizations is called upon to play the role of system regulator, in order to keep operations in tune and harmony, with the environment. As productivity catalyst, organization have to take into account both economic and social inputs (cost) and economics and social outputs (benefits) in planning, formulating and evaluating business projects. (Cole,2002) observed that corporate social responsibility is one important areas of policy development, which implies that business and their managers are required to play more than just economic role in the society. They are expected by the society to play direct role in meeting community needs in the arts, education, health and environmental matters, and social welfare. These are in addition to their roles as employers and producers. Many firms have developed their own social or community's programmes, the objective being to demonstrate that business organizations are just as capable as individuals of being good citizens.

\section{Corporate Social Responsibility And Organizational Effectiveness}

(Lawal and Sulaimon 2007) predicted a positive relationship between corporate social responsibility and organizational effectiveness, the findings of their study revealed that involvement in social responsibility turned out to be one of the determinants of organizational effectiveness, being socially responsible can help SMEs to succeed, increase profit and overall performance. However, for SMEs to be acknowledged as socially responsible, they need not to focus only on business ethics and urban affairs but also on environmental affairs. Environmental sustainability and growth have been the focus of attention in recent years, although, in the past years, most organizational policies on SMEs focus on growth at the expense of environmental quality, these policies were premised on the expectation that gains in material well-being would far exceed losses incurred in environmental degradation. Realistically, SMEs may simply be contented to survive as long as they are making decent living. Hence, there is little need to engage in environmental sustainability.

In the light of the prevailing threat to human, animal and plant, this attitude has gradually reversed. All over the globe, quest for environmental management, quality of life and sustainable growth has gained attention of contemporary organizations, this perhaps may be responsible for United Nation declaration of June 5 as the World Environmental Day, a day earmarked for governments across the globe to discuss and recommend ways of improving the environment (Lawal and Sulaimon, 2007). They noted further that SMEs are only motivated to adopt environmental management policies by legislations and chain pressures, the former is unlikely to be readily accepted by resource constrain of SMEs and the latter in any way just transfers the large firms agenda into the smaller firms without accounting for the complex and heterogeneous nature of this sub-sector.

To cope with the issue of environmental management, SMEs need not only to develop specific activities and strategic responses at organizational level but also facilitate the evolution of managerial values and beliefs toward higher level of environmental management, in addition, there is need for governments backing of environmental management by assisting SMEs that are involved in environmental sustainability, as they constitute the vast majority of the Nigerian private sector.

Empirical results of the relationship between corporate social responsibility and corporate performance have been inconclusive. One of the reasons for lack of consensus is the absence of meaningful measures of corporate social responsibility (Stanwick and Stanwick, 1998).

In a survey of 130 manufacturing firms, (Wokutch and Spencer, 1983) classified participating firms under four main groups on the basis of crime involvement and philanthropic contributions. These groups correspond to the following behavioural categories:

> Saints: No crime and high contributions

Pharises: No crime and low contributions 
Corporate Social Responsibility And Effectiveness Of Small And Medium Enterprises (Smes) In

$>$ Cynics repenters: Crime and high contributions

$>$ Sinners: High crime and low contributions.

An analysis of the financial performance of these groups revealed that the sinners performed significantly worse than the other groups on both performance measures. Consistent with this finding are studies conducted by (Adernson and Frankle 1980) this study revealed that the cost of having a high level of social responsibility was more offset by the increased benefits in employees' morale and productivity. Two main explanations offered by (Wokutch and Spencer 1987) to support the positive relationship between corporate social responsibility and performance are the fact that sinners may have been penalized in the market place for their social performance and socially responsible corporations are rewarded in the market place. The second reason is the effect of the industry on the relationship between corporate social responsibility and financial performance. Meanwhile,(Ingram and Fraiser 1983) and (Freedman and Jaggi 1985) reported a negative relationship by supporting the view that the cost of being socially responsible forces out firms into an unfavorable position.

\section{Corporate Social Responsibility Model}

The various areas of corporate social responsibility discharge are presented in the figure below; the various areas include: Economic, legal, ethical, discretionary and total responsibilities.

Figure 1: CORPORATE SOCIAL RESPONSIBILITY MODEL (HIERARCHICAL APPOACH) TOTAL

RESPONSIBILITY

DISCRETIONARY

RESPONSIBILITY

ETHICAL

RESPONSIBILITY

\section{LEGAL}

RESPONSIBILITY

\section{ECONOMIC}

RESPONSIBILITY

Source: Adapted from (Ogundele, 2007), Introduction to entrepreneurship development, corporate governance and small business management, Molofin nominees. pp 128.

Economic responsibility: This is base level of the itinerary; it involves returns to owners and shareholders, creations of job, fair play for workers, innovation, efficient utilization of resumes etc.

Legal responsibility: This relates to complying with legal legislations imposed by the government and regulatory agencies. It means that corporations that want to be ethical must be the economically, and legally responsible.

Ethical responsibility: Those activities expected of corporations as members of the society, which are not defined by laws. This shows corporation as being moral, doing things, just and fair.

Discretionary responsibility: This concerns group activities and actions that are the result of organizations discretions rather than legal demands or ethical norms. Examples are philanthropic contributions, sponsorship, and educational development.

Total responsibility: This is an aggregation of the four responsibilities listed above. It means that corporations that want to be ethical must be economically and legally responsible. Economic and legal responsibilities are socially required. Ethical responsibility is socially expected and discretionary responsibility is socially required.

\section{APPROACHES TO CORPORATE SOCIAL RESPONSIBILITY}

(Bennett, 1998) and (Cole, 2002) identified two broad ways of encouraging SMEs

To develop a sense of corporate social responsibility. These are:

* Laissez-faire or voluntary approach

* State interruption or force of law approach

* Nigeria experience has produced the third approach which is coercion by the local communities

Lassez-faire or voluntary approach: The argument her is that most firms are likely to operate social responsibility programmes from the point of view of enlightened self- interest. A firm's reputation can be 
Corporate Social Responsibility And Effectiveness Of Small And Medium Enterprises (Smes) In maintained in society by contributing to those activities, which are never sufficiently funded by the state. Today firms contribute in promoting, arts and social welfare. Firm's objectives for contributing to or engaging in social responsibility programmes range from the highest altruism to the most calculating self- interest. (Cole 2002).

State intervention or the force of law approach: This approach asserts that state intervention is essential to ensure that firms do not misbehave. Large enterprises have enormous economic power; as such they can manipulate communities and appropriate for themselves revenue far in excess of those justified by their contributions to the society. (Bennett,1998) notes that firms are able to initiate social change. I is, therefore, only reasonable that society, through its elected representatives, determine the direction of the changes that occurred. Moreover, firms are components of a wider social system and are of necessity concerned with social issues like, income and employment, health and safety, labour relations, occupational raining etc. This implies that some managerial prerogatives have to be surrendered for the common good. (Cole 2002) notes that state laws play important role in regulating the relationship between firms and their various stakeholders.

Coercive approach by the local community: (Ogundele 2005) Notes that in the case of Nigeria a new dimension had been introduced to the demand for the discharge of social responsibility by big organizations and even small ones. This is the coercive approach by the local community in which the organization is located. A ready example would be the forceful and physical occupation of the premises of multinational Oil corporations' e.g Shell BP in the oil producing area in Nigeria. These local communities argue that the oil companies, that contribute to the damage of the environment, and who are making huge profits, should be directly responsible for reconstructing the damaged physical, water and natural environment. They are also asked to provide means of livelihood for the inhabitants who have been thrown out of their traditional occupations consequent on the negative effect of oil explorations. The recent dimension on these coercive demands is the constant detention of employees of the multinational oil companies as hostages by vigilante groups in Delta area in Nigeria. In the case of Lagos metropolis, a new pattern of forceful demand of social responsibility obligations had been introduced in the transportation service section. Unemployed youths and adult forcefully extort money from commercial vehicles plying the roads and the state government is completely helpless in tackling this social problem. Also whenever an important ceremony or function is been held by the land owners, tenants are forced to make contribution towards funding such ceremony as part of their social responsibility to the family who originally owned the land they possessed newly.

\section{ACTIVITIES AND ELEMENTS OF CORPORATE SOCIAL RESPONSIBILITY BY SMES IN NIGERIA}

(Lawal and Sulaimon 2007) in the report of their study on discharge of social responsibility obligation by SMEs in Nigeria employed four activities namely; Business ethics, Urban affairs, Consumer affairs and environmental affairs, with each of them having five elements as shown in figure below. The study sought to establish relationship between the discharge of social responsibility obligations and organizational effectiveness of a group of SMEs in Nigeria.

Figure2: Activities and elements of corporate social responsibility

\begin{tabular}{|l|l|}
\hline BUSINESS ETHICS: & URBAN AFFAIRS: \\
Avoiding fake product & Employment and training \\
Avoiding product misrepreresentation & Education \\
Avoiding discrimination & Medical assurance \\
Avoiding deceptive advert & Culture and art \\
Avoiding the use of lottery & Urban renewal \\
\hline CONSUMER AFFAIRS & ENVIRONMENTAL AFFAIRS \\
Quality control & Water pollution \\
Design improvement & Air pollution \\
Consumer service & Waste disposal \\
Market improvement & Noise abatement \\
Market information & Radiation abatement \\
\hline
\end{tabular}

Source: Adapted from (Ogundele 2007) Entrepreneurship development, corporate governance and small business management, Molofin nominees. pp 132

From their study, the following findings were reported on each of the activities:

Business ethic: Avoiding production of fake product attracted the most active involvement in business ethics of SMEs, followed by avoiding product misrepresentation, and misleading advertising. No discrimination in hiring and avoiding lottery are least social issues involved by participating enterprises. 
Corporate Social Responsibility And Effectiveness Of Small And Medium Enterprises (Smes) In

Urban affairs: The activities attracting the attention of participating organizations are employment and training contribution to education and medical assistance.

Customer affairs: This appears to be the area where majority of participating respondents indicate high level of involvement in all dimensions.

Environmental affairs: All the respondents indicate least involvement in the programme. This indicates that SMEs are yet to recognize the fact that a business must be a friend of the environments.

\section{Methodology}

For the purpose of achieving the objective of this research, a cross- sectional survey design was employed to assess the social responsibility practice of SMEs across different industries operating in Lagos. Primary data were generated through self-administered questionnaires to the participating firms to determine their social responsibility practices. The population of the study comprised SMEs operating within Lagos State. The selection of Lagos was based on the fact that despite the movement of the seat of administration to Abuja, the state still maintains its role as the commercial centre. Lagos state ministry of commerce and industry was approached for detailed information on SMEs in Lagos an the request was directed to Lagos state branch of Nigerian Association of Small-Scale Industrialists (NASSI) in Matori on the premise that government programmes on SMEs development are executed in collaboration with NASSI the umbrella body for SMEs in Lagos.300 copies of questionnaires were sent out to the various SMEs across Lagos, and 209 were properly filled and returned. In each participating firms, five employees were selected randomly. Descriptive statistics such as percentage, mode, median and standard deviation was employed to measure social responsibility practices of the responding SMEs, and Product moment correlation (r) was employed to ascertain the association between each pair of the variables and inter-correlation among them. Data processing and analysis were carried out with the aid of Statistical Package for Social Sciences (SPSS) software. In addition, all the statistical tests and analysis were conducted at the conventional $95 \%$ of confidence.

\section{RESEARCH HYPOTHESIS}

Ho: Involvement in corporate social responsibility and organizational effectiveness are not significantly related. Ha: Involvement in corporate social responsibility and organizational effectiveness are significantly related.

DATA PRESENTATION AND ANALYSIS

Figure 3: Classification of data based on the responding SMEs

\begin{tabular}{|l|l|l|}
\hline \multicolumn{1}{|c|}{ Classes of SMEs } & No of Firms & Percentage \\
\hline Manufacturing (Fabrication) & 95 & 45.45 \\
\hline Chemicals & 11 & 5.26 \\
\hline Textile & 4 & 1.91 \\
\hline Electronic & 3 & 1.44 \\
\hline Glass and Ceramic & 1 & 0.58 \\
\hline Agro-Allied & 3 & 1.44 \\
\hline Furniture & 11 & 5.26 \\
\hline Leather and Footwear & 3 & 1.44 \\
\hline Nylon Production & 14 & 6.70 \\
\hline Food and Drinks & 27 & 12.92 \\
\hline Health Care & 5 & 2.39 \\
\hline Others & 32 & 15.31 \\
\hline Total & 209 & 100 \\
\hline Source & &
\end{tabular}

Source: Field survey 2012

Figure 4: Number of employees in the selected SMEs

\begin{tabular}{|l|l|l|}
\hline \multicolumn{1}{|c|}{ No of Employees } & NO of Firms & Percentage \\
\hline $10-20$ & 107 & $\mathbf{5 1 . 1 9}$ \\
\hline $21-30$ & 26 & 12.44 \\
\hline $31-40$ & 15 & 7.18 \\
\hline $41-50$ & 14 & 6.70 \\
\hline $51-100$ & 47 & 22.49 \\
\hline Total & 209 & 100 \\
\hline
\end{tabular}

Source: Field survey 2012. 
Figure 5: Years of Existence of the SMEs

\begin{tabular}{|l|l|l|}
\hline \multicolumn{1}{|c|}{ Existence } & No of Firms & Percentage \\
\hline Less than 5years & 48 & 22.97 \\
\hline $5-20$ years & 116 & 55.50 \\
\hline $21-$ 30years & 45 & 21.53 \\
\hline Total & 209 & 100 \\
\hline
\end{tabular}

Source: Field survey 2012.

Figure 6: Areas of involvement of SMEs in Corporate social responsibility

\begin{tabular}{|c|c|c|c|c|c|}
\hline Areas & Mean & S.D & S.E & $\begin{array}{l}95 \% \text { C } \\
\text { Differe }\end{array}$ & ce Interval of \\
\hline & & & & Lower & Upper \\
\hline BUSINESS ETHICS: & & & & & \\
\hline Avoiding fake product & 2.74 & 0.74 & 0.051 & 2.64 & 2.64 \\
\hline Avoiding & 2.05 & 0.81 & 0.056 & 2.54 & 2.54 \\
\hline misrepresentation & 2.08 & 0.54 & 0.065 & 1.95 & 1.95 \\
\hline Avoiding discrimination & 2.41 & 1.02 & 0.070 & 2.27 & 2.27 \\
\hline $\begin{array}{l}\text { Avoiding deceptive advert } \\
\text { Avoiding the use of lottery }\end{array}$ & 1.58 & 1.09 & 0.075 & 1.44 & 1.44 \\
\hline URBAN AFFAIRS: & & & & & \\
\hline Employment and training & 2.72 & 0.54 & 0.037 & 2.66 & 2.66 \\
\hline Education & 2.33 & 0.83 & 0.058 & 2.21 & 2.21 \\
\hline Medical assurance & 2.37 & 0.77 & 0.054 & 2.26 & 2.26 \\
\hline Culture and art & 1.67 & 0.92 & 0.063 & 1.54 & 1.54 \\
\hline Urban renewal & 1.79 & 0.92 & 0.063 & 1.66 & 1.66 \\
\hline CONSUMER AFFAIRS: & & & & & \\
\hline Quality control & 2.86 & 0.49 & 0.34 & 2.80 & 2.93 \\
\hline Design improvement & 2.61 & 0.67 & 0.46 & 2.52 & 2.70 \\
\hline Consumer service & 2.77 & 0.53 & 0.37 & 2.70 & 2.84 \\
\hline Market improvement & 2.66 & 0.65 & 0.45 & 2.57 & 2.75 \\
\hline Market information & 2.69 & 0.20 & 0.14 & 2.42 & 2.97 \\
\hline ENVIRONMENTAL AFFAIRS: & & & & & \\
\hline Water pollution & 1.15 & 1.25 & 0.86 & 0.98 & 1.32 \\
\hline Air pollution & 1.09 & 1.20 & 0.83 & 0.93 & 1.25 \\
\hline Waste disposal & 1.97 & 1.09 & 0.74 & 1.86 & 2.12 \\
\hline Noise abatement & 1.70 & 1.07 & 0.74 & 1.50 & 1.84 \\
\hline Radiation abatement & 1.68 & 1.14 & 0.79 & 1.53 & 1.84 \\
\hline
\end{tabular}

Source: field survey 2012

Figure 7: Correlation between corporate social responsibility involvement and organizational effectiveness of participating SMEs.

\begin{tabular}{|c|c|c|c|c|c|}
\hline \multirow[t]{2}{*}{$\mathbf{S} / \mathbf{N}$} & \multirow[b]{2}{*}{ Effectiveness Criteria } & \multicolumn{4}{|c|}{ Measure of Corporate social Responsibility } \\
\hline & & $\begin{array}{l}\text { Business } \\
\text { Ethics }\end{array}$ & $\begin{array}{l}\text { Urban } \\
\text { Affairs }\end{array}$ & $\begin{array}{l}\text { Consumer } \\
\text { Affairs }\end{array}$ & $\begin{array}{l}\text { Environmental } \\
\text { Affairs }\end{array}$ \\
\hline 1 & Profitability & 0.100 & $0.149 * *$ & 0.088 & -134 \\
\hline 2 & Growth rate & 0.103 & 0.237 & 0.115 & -058 \\
\hline 3 & Financial strength & 0.103 & $0.262 * *$ & $0.154 *$ & -018 \\
\hline 4 & Operation efficiency & 0.038 & 0.109 & 0.32 & -036 \\
\hline 5 & Performance stability & 0.056 & $0.280 * *$ & $0.97 *$ & -035 \\
\hline 6 & Public image & 0.041 & $0.211 * *$ & $0.275 * *$ & -073 \\
\hline 7 & Staff morale & 0.075 & $0.186 * *$ & $0.158 *$ & -047 \\
\hline 8 & Adaptability & $0.134 *$ & $0.201 * *$ & $0.113 * *$ & -022 \\
\hline 9 & Innovativeness & $0.172 *$ & $0.137 *$ & $0.221 * *$ & -068 \\
\hline 10 & Social impact & 0.015 & 0.124 & 0.069 & -031 \\
\hline 11 & Organizational commitment & 0.007 & $\mathbf{0 . 0 5 0}$ & $\mathbf{0 . 0 2 7}$ & -030 \\
\hline 12 & Job satisfaction & 0.085 & 0.022 & 0.010 & -028 \\
\hline
\end{tabular}

Source: Field survey, 2012 
It should be noted that;

$* \mathrm{P}<0.05$

$* * \mathrm{P}<0.01$

In the hypothesis earlier states, a significant relationship was predicted between corporate social responsibility and dimension of effectiveness. As presented in figure 7 above, the correlation between dimension of corporate social responsibility and organizational effectiveness of responding firms generated 48

coefficients and 15 are statistically significant at $\mathrm{P}<0.05$ and above. This indicated that; Profitability is significantly related to urban affairs Financial strength is positively related to consumer and urban affairs Performance stability is significantly related to urban affairs and consumers affairs. Staff morale is significantly related to urban affairs and consumer affairsAdaptiveness is significantly related to business ethics, urban affairs and consumer affairsOnly environmental affairs that are not significantly related to any of the dimensions of organizational effectiveness.

\section{Discussion And Conclusion}

The findings of this study recognize the overriding fact that there is growing concern for corporate social responsibility activities in the SMEs. It is clearly revealed that many SMEs engage in some kind of silent social responsibility, hose that attract the attention of participating firms are business ethics, customer and urban affairs. However, majority of the responding firms reported their least involvement in the environmental affairs. This finding is consistent with the result of previous studies conducted by (Lawal and Sulaimon 2007).

Evidence from this research indicates that SMEs may constitute one of the largest portions of the industrialists considered as worst enemies of the environment. It is an open secret that SMEs misuse the environment more than the large enterprises. The bulk of environmental problems such as envision of matter, indiscriminate discharge of noxious matter, blocking of drains and littering of streets with refuse and their dirt are to some extent attributed to SMEs. This may be due to the fact that large-scale enterprises provide relatively easy target for the government in terms of regulations and control of pollution, hence smaller firms tend to misuse the environment more than the large organizations. While the growing visibility and global impact of large corporations has heralded greater transparency, accountability and brand image $\mathrm{n}$ the environmental management, SMEs remain largely invisible in terms of risk and brand image.

\section{Recommendation}

Base on the findings of this research, it is recommended that to cope with the issues of environmental management, SMEs need not only to develop specific activities and strategic responses at organizational level but also facilitate the evolution of managerial values and beliefs toward corporate social responsibility and higher level of environmental management. In addition, there is need for governments backing of environmental management by assisting SMEs that are socially responsible and involve in environmental sustainability, as they constitute the vast majority of the Nigerian private sector.

References

[1] Abott,W.F and Mossan, J. (1979): The measurement of corporate social responsibility, Academy of management journal pp.22, $501-515$

[2] Acs, Zoltan, Randall et'al (1999): Productivity growth and size distribution, IN Zoltan Acs, Bo Carlson, and Charlie Kartson, ed., Entrepreneurship, small and medium- size enterprises and macro-economy. Cambridge university press.

[3] Allen, N.J. and Meyer, J.P. (1990): The measurement and anteradent of effective continuance and normative commitment to organization, Journal of occupational psychology, pp. 63.

[4] Andrew, K. (1977): Key to social responsibility, as cited in A deleke, P. in Managing Nigerians' economic system. By Inanza, E. (1985), Nigeria Heimeman Educational books.

[5] Angle, H. and Perry, J. (1987): Organizational commitment, individual and organizational influences work and occupational. Pp 223-242

[6] Asika, N.(1991): Research methodology in the behavioral science, Lagos, Longman Nigeria Plc.

[7] Bower, J.L. (1983): The two faces of management in business and politics. Boston Mifflin publishing company.

[8] Bowmer, E.H. and Haira, M. (1975): A strategic posture towards corporate social responsibility,California management review. Pp 49-58.

[9] Butcher, V.M. and Shetty, I. (1976): Management response to social responsibility, Academy of management journal. 34 Pp5-47

[10] Cole, G.A.(2002): Management theory and practice. The London: Harper and Printer Ltd.

[11] European Union green paper, (2001): Promoting a European framework for corporate social responsibility, Brussels commission for European communities.

[12] Forster, R. (2002): Corporate social responsibility: Implication for SMEs in developing countries. IFC working paper, 30.

[13] Frankfort, N.C. and Nichman, D. (1996): Research methods in the social sciences, London, Oxford University press.

[14] Ikpeze, N. (1981): Business social responsibility: Its concepts and practical difficulties, Management in Nigeria.

[15] Lawal, A.A.(1993): Management in focus, Lagos, Abdul industrial enterprises.

[16] Lawal, A.A. and Sulaimon, A. (2007): Social responsibility and organizational effectiveness of SMEs in the contemporary environment. Journal of Environment, value and policies in Nigeria, Lagos. EBAN, pp. 153- 174. 
[17] Lawal, A.A., Sulaimon, A. and Adebayo, O.(1993): Entrepreneurship in small business enterprises, Lagos, Labson resources limited.

[18] Lincoln, A. (1989): Employee work attitude and management practice in U.S and Japan, Evidence from Large comparative survey, California management review, pp 89- 100.

[19] McGuire, J., Sandgreen, A. and Schnewis, T. (1998): Corporate social responsibility and firm financial performance, 31, pp 854-872.

[20] Ogbeuchi, A. (1998): Promoting international business ethics and integrity, Management in Nigeria, April - December.

[21] Ogundele, O.J.K.(2005): Management and organization, Theory and behaviour, Lagos: Molofin Nominees

[22] Ogundele, O.J.K. (2007): Introduction to entrepreneurship development, corporate governance and small business management, Lagos. Molofin Nominees. pp 125-135.

[23] Stanwick, P.A., and Stanwic K.A. (1998): The relationship between corporate social performances, Organization.

[24] Wokutch, R.F. and Spencer, B.A. (1984): Corporate saints and seminars: The effect of philanthropic and illegal activity on organizational performance, California management review, 29 pp 62-76.

[25] World business council for sustainable development (2001): Corporate social responsibility: Making good business sense, WBCSD. 